\title{
APLIKASI DIAGNOSA SINDROM NOMOPHOBIA PADA REMAJA DENGAN SISTEM PAKAR BERBASIS ANDROID
}

\author{
Herdin Muryanto ${ }^{1}$, Supatman ${ }^{2}$ \\ ${ }^{1)}$ Program Studi Teknik Informatika, Fakultas Teknologi Informasi, Universitas Mercu Buana Yogyakarta \\ ${ }^{1}$ herdin.email24@gmail.com \\ ${ }^{2}$ Program Studi Teknik Informatika, Fakultas Teknologi Informasi, Universitas Mercu Buana Yogyakarta \\ 22supatman@mercubuana-yogya.ac.id
}

\begin{abstract}
Abstrak
Seiring berkembangnya teknologi dan alat komunikasi modern, handphone salah satunya sebagai alat komunikasi dan mesin pencari informasi di era teknologi di kalangan remaja yang berdampak negatif pada kesehatan mental dan emosional remaja jika tidak dapat mengontrol diri dalam penggunaannya. Fenomena ini disebut nomophobia (no-mobile phone phobia) yang merupakan jenis fobia baru yang ditandai dengan ketakutan dan ketakutan yang berlebihan jika seseorang tdak dapat terhubung ke ponselnya. Untuk mengetahui apakah memiliki fobia ponsel adalah langsung dengan psikologi. Namun terdapat beberapa orang yang tidak dapat meluangkan waktu dan mengeluarkan uang untuk kegiatan psikologi.

Dengan adanya permasalahan tersebut, pada penelitian ini bertujuan untuk merancang sebuah aplikasi diagnosa nomophobia untuk remaja berbasis android. Penelitian ini didasarkan pada pengetahuan ahli psikologi yang diperoleh melalui metode wawancara. Aplikasi diagnosa ini berjalan pada perangkat mobile Android dengan bahasa pemrograman Java dan menggunakan metode sistem pakar. Berdasakan hasil pengujian dari diagnosa pakar dan diagnosa sistem diperoleh tingkat akurasi sebesar $100 \%$ dari 17 data uji dan tingkat penerimaan pengguna untuk aplikasi cukup baik pada uji UAT yang dilakukan ke 11 remaja sebesar $84,21 \%$. Sehingga diharapkan dapat membantu remaja dalam mendiagnosa fobia nomophobia ini sejak dini dan memberikan solusi pencegahannya.
\end{abstract}

Kata kunci: android, nomophobia, sistem pakar, aplikasi

\section{PENDAHULUAN}

Semakin pesatnya perkembangan teknologi di tahunnya memberikan banyak kemudahan untuk memenuhi segala aspek kebutuhan manusia, apalagi di masa pandemi Covid-19 ini yang semakin meningkat memberikan ide-ide baru untuk mempermudah manusia melakukan aktivitas dari jarak jauh atau online. Salah satu media telekomunikasi yang berkembang pesat dan paling sering digunakan untuk memunculkan "budaya seluler" adalah telepon genggam (Ezemenaka, 2013).

Dengan semakin mudah didapatkan dan semakin lengkap fungsi smartphone akan membuat banyak pengguna memiliki rasa ketergantungan terhadap perangkat tersebut. Ketergantungan ini akan berdampak negatif pada kesehatan fisik dan psikis pengguna akibat penggunaan smartphone yang berlebihan. Dari segi kesehatan fisik, penggunaan smartphone secara berlebihan dapat merusak kesehatan mata, menyebabkan ketegangan otot leher dan masih banyak lagi.
Sedangkan dampak dari segi psikologis, penggunaan smartphone yang berlebihan akan menimbulkan perasaan cemas jika jauh dari smartphone atau biasa disebut nomophobia (Nareza, 2020).

Nomophobia atau disebut juga nomobile-phone-phobia adalah sebuah perasaan ketergantungan pada ponsel yang merupakan gangguan emosional baru di abad 21 yang mengakibatkan perasaan gelisah dan tidak nyaman yang berlebihan ketika seseorang tidak memegang smartphone (King \& dkk, 2014).

Pada umumnya seorang psikolog akan melakukan proses konseling dengan mengajukan beberapa pertanyaan kepada seorang pasien untuk akhirnya mendapatkan diagnosa dari masalah yang dialami pasien tersebut. Dengan aplikasi diagnosa nomophobia menggunakan sistem pakar ini, baik seorang ahli maupun pengguna awam akan merasa mudah untuk mendeteksi masalah yang dihadapi. Oleh karena itu, untuk mempermudah seorang remaja atau pengguna 
lain untuk memantaui apakah memiliki fobia tersebut maka peneliti mengambil judul "Aplikasi Diagnosa Sindrom Nomophobia Pada Remaja Dengan Sistem Pakar Berbasis Android" agar dapat mendiagnosis fobia nomophobia sejak dini dan dapat melakukan langkah penanganannya dengan segera.

\section{TINJAUAN PUSTAKA}

Beberapa penelitian terkait, seperti penelitian "Aplikasi Sistem Pakar Diagnosa Tingkat Depresi Pada Remaja Dengan Metode Forward Chaining Berbasis Android" yang bertujuan untuk mendiagnosa tingkat depresi menggunakan aplikasi android dengan metode Forward Chaining kepada 15 responden yang masih remaja di Dalam penelitian ini terdapat 4 tingkat depresi dengan 20 kriteria gejala yang digunakan sebagai parameter dalam mengidentifikasi depresi pada setiap responden remaja. Berdasarkan data yang telah diujikan sebanyak 15 responden yang menggunakan sistem, didapatkan adanya kesesuaian antara metode yang telah diterapkan dengan sistem yang memiliki tingkat akurasi sebesar 93\% (Putri \& Rifki, 2020).

Penelitian "Konsep Nomofobia pada Remaja Generasi Z" yang dilakukan Sari, Ifdil dan Yendi pada tahun 2020 memberikan informasi mengenai faktor-faktor yang menyebabkan Generasi $\mathrm{Z}$ lebih cenderung terkena nomofobia dibandingkan orang dewasa. Dalam penelitiannya mereka juga memberikan langkah-langkah terbaik untuk mengatasi nomophobia secara mandiri pada Generasi Z (Sari, Ifdil, \& Yendi, 2020).

Penelitian "Studi Tingkat Kecemasan Remaja Terhadap No-Handphone (Nomophobia) di SMA Negeri Kota Padang" menentukan penentuan tingkat kecemasan remaja terhadap tidak ada ponsel (nomophobia) di SMA Negeri Kota Padang. Tujuan dari penelitian ini adalah untuk mengetahui tingkat kecemasan remaja dengan handphone. Penelitian ini menggunakan metode analitik kuantitatif dengan desain cross sectional dengan 75 remaja di SMA Negeri 5 dan SMA Negeri 7 Padang. Hasil penelitian ini menunjukkan bahwa ada hubungan antara intensitas penggunaan Facebook dengan kecenderungan menjadi nomophobia pada remaja (Rahayuningrum \& Sary, 2019).
Penelitian "Sistem Pakar Mendiagnosis Depresi Pada Mahasiswa Akhir Dengan Menggunakan Metode Faktor Kepastian Berbasis Mobile" yang dilakukan oleh Apip Supiandi dan Damar Bagja Chandradimuka pada tahun 2018 ini merupakan sistem pakar berbasis android untuk mendiagnosis depresi pada mahasiswa. Penelitian menggunakan metode Certainty Factor dengan 15 gejala dan 7 nilai pembobotan. Output yang dihasilkan adalah tingkat depresi pada mahasiswa tingkat akhir dengan diagnostik berbasis aplikasi mobile (Supiandi \& Chandradimuka, 2018).

Penelitian "Perancangan Aplikasi Identifikasi Gaya Belajar Siswa Dengan Metode Forward Chaining" mengenai identifikasi gaya belajar siswa dengan menggunakan metode forward chaining yang diterapkan pada program android memberikan hasil yang tepat untuk pemilihan gaya belajar bagi siswa yang mengalami kesulitan dalam belajar tertentu. metode pembelajaran. Metode penelitian dilakukan dengan mewawancarai guru dan siswa di SD Negeri Sumampir. Menghasilkan identifikasi gaya belajar yang tepat untuk setiap siswa (Ibrohim \& Purwanty, 2017).

\section{METODE PENELITIAN}

Penelitian ini menggunakan metode waterfall yang disusun secara sistematis di setiap tahapnya dalam kerangka berpikir yang meliputi metode dalam menganalisis data dan metode pengembangan sistem. Sistem ini dibagi menjadi lima tahapan sistematis, yaitu kebutuhan, perancangan sistem, representasi pengetahuan \& pengkodean, pengujian dan implementasi program.

a. Analisis Data

Dalam tahap ini dilakukan observasi untuk mencari permasalahan sehingga didapatkan tujuan penelitian yang ingin dicapai adalah membangun program aplikasi diagnosa nomophobia pada remaja berbasis android. Untuk mendapatkan teori yang relevan dengan penelitian ini, informasi dicari dengan cara sebagai berikut

1) Pengumpulan data melalui wawancara dengan seorang ahli yang menekankan diagnosis gejala pada nomophobia sesuai dengan tingkat kecanduan dan solusi untuk penanganannya. 
2) Studi literatur dengan mempelajari jurnal, buku, artikel dan referensi yang berhubungan dengan penelitian yang dilakukan.

b. Representasi pengetahuan

Pada tahap ini data yang telah di dapatkan kemudian diolah dengan menggunakan metode yang sesuai. Aplikasi diagnosa ini menggunakan metode sistem pakar dimana seorang pakar (misalnya psikolog) sering menganalisis informasi yang ada dengan menghubungkan premis (IF) dan kesimpulan (THEN) seperti yang digunakan dalam metode sistem pakar forward chaining. Lalu mendapatkan kepastian dari hasil diagnosanya antara premis dan kesimpulan etrsebut dengan ukuran persentase (\%) yang biasa digunakan dalam metode certainty factor.

c. Perancangan Sistem

Dalam tahap perancangan sistem peneliti membuat sebuah gambaran agar sistem dapat dioperasikan dengan lancar dan mudah bagi pengguna awam yang baru pertama kali mencoba.

d. Implementasi Program

Tahap selanjutnya peneliti mulai membuat sistem sesuai dengan rancangan desain dan hasil dari representasi pengetahuan yang dimasukkan kedalam bahasa sistem aplikasi android.

e. Pengujian

Dalam tahap ini peneliti mulai melakukan pengujian sistem yang telah dibuat yang kemudian akan di dapatkan sebuah kesimpulan dan saran.

\section{HASIL DAN PEMBAHASAN}

a. Tampilan Antarmuka

1) Antarmuka Splash Screen

Antarmuka splash screen akan menampilkan gambar splash screen aplikasi selama 4 detik. Setelah 4 detik akan muncul antarmuka halaman login. Berikut gambar dari antarmuka splash screen aplikasi.

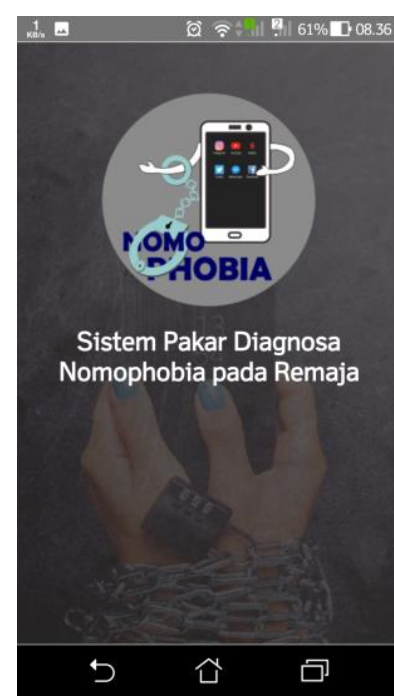

Gambar 1. Antarmuka Splash Screen

\section{2) Antarmuka Login}

Untuk dapat masuk ke menu beranda user diharuskan login terlebih dahulu pada halaman login atau melakukan pendaftaran akun pada tombol daftar yang tersedia. Semua kolom login harus terisi, jika terdapat kolom yang kosong atau salah akan memunculkan peringatan sesuai kesalahan.

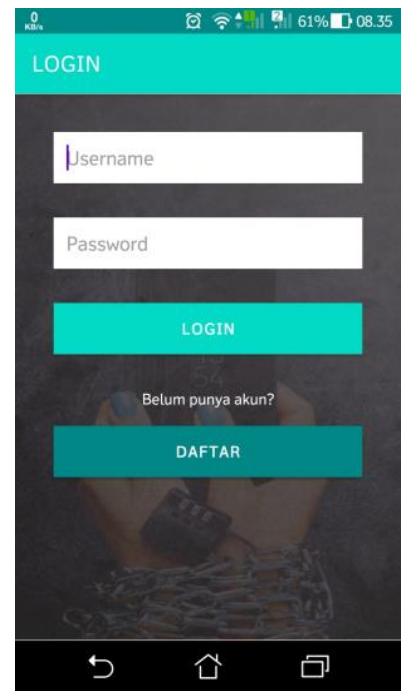

Gambar 2. Antarmuka halaman Login

3) Antarmuka Daftar

Interface daftar akan muncul saat menekan tombol daftar pada halaman login. User diharuskan mengisi semua data pada kolom yang ada yang nantinya akan tersimpan pada database sistem, dan dapat langsung menuju proses login. Login terbagi menjadi 2 role pengguna yaitu admin dan user pada halaman pendaftaran ini hanya berguna untuk mendaftar sebagai role user. 


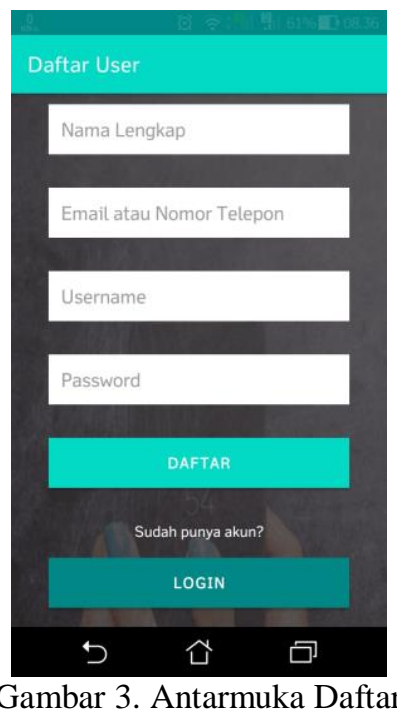

4) Antarmuka Beranda

Antarmuka beranda dibagi menjadi 2 versi sesuai role akun yang digunakan dalam proses login yaitu beranda admin dan beranda user. Berikut penjelasan dari setiap versi beranda yang ada berdasarkan role akun login.

- Antarmuka Admin

Pada beranda admin terdapat 4 menu yang dapat digunakan untuk mengatur proses diagnosa user seperti gejala, level, rule dan tombol keluar.

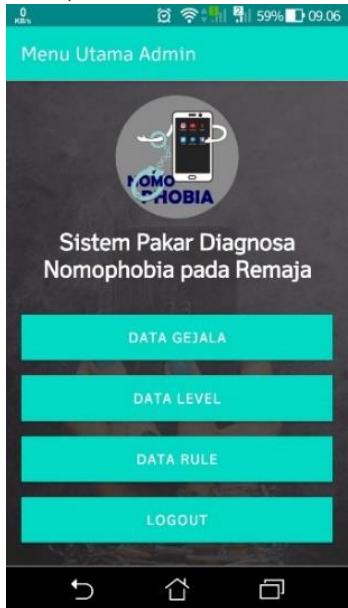

Gambar 4. Antarmuka Home Admin

- Antarmuka User

Pada Tampilan Beranda, ini akan menampilkan semua menu yang ada di dalam sistem. Adapun menu yang tersedia yaitu menu Materi, menu Diagnosa (deteksi), menu Riwayat, menu Tentang, dan tombol Logout.

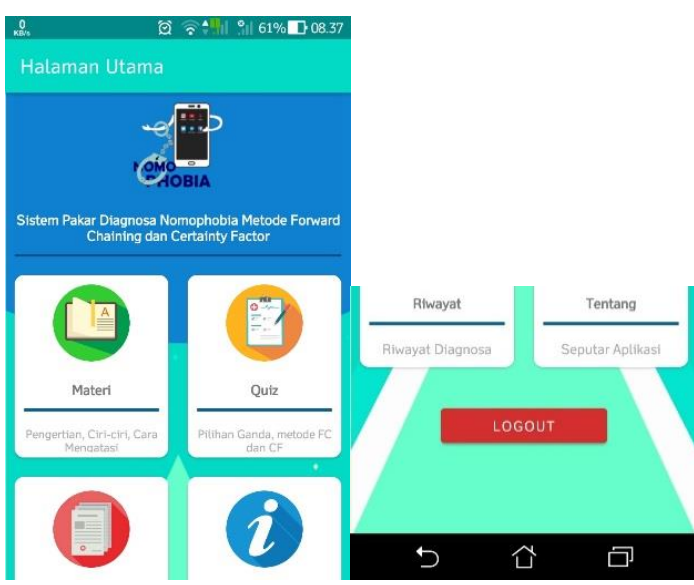

Gambar 5. Antarmuka Home User

5) Antarmuka Materi

Antarmuka materi ini berisikan informasi seputar nomophobia serta tombol untuk kembali ke halaman beranda.

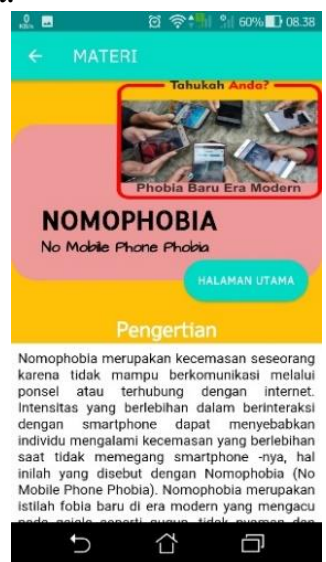

Gambar 6. Antarmuka Menu Materi

6) Antarmuka Diagnosa

Antarmuka ini berisikan pertanyaan-pertanyaan mengenai gejalagejala yang dialami oleh user kemudian dari jawaban user akan didapatkan sebuah hasil diagnosa. Pertanyaan diagnosa terdapat sebanyak 8 pertanyaan yang akan diproses menggunakan metode Forward Chaining hingga menampilkan hasil diagnosa berupa level nomophobia yang dialami. 


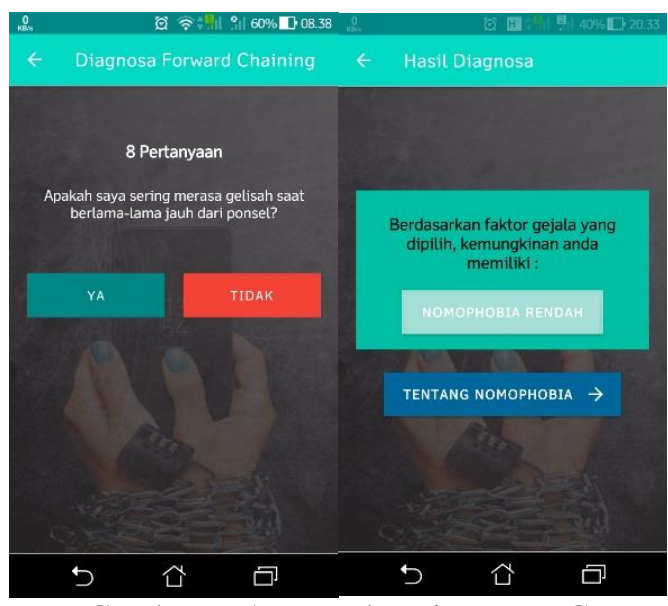

Gambar 7. Antarmuka Diagnosa FC

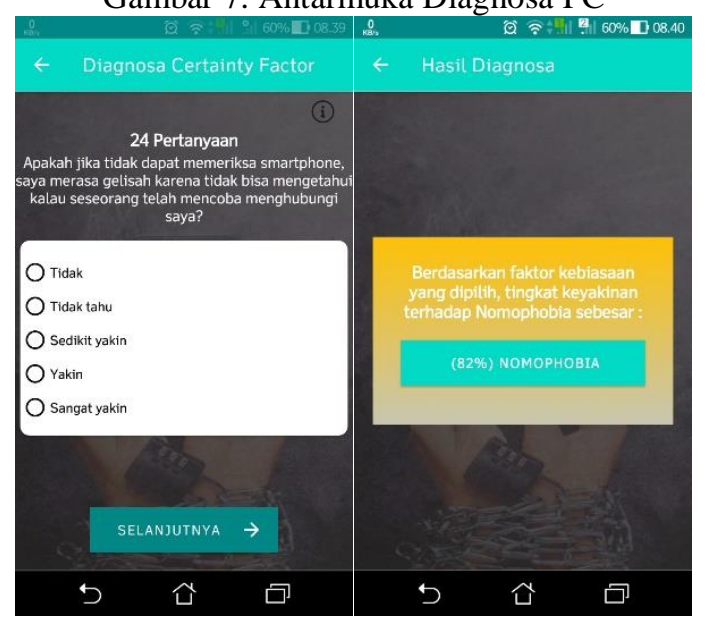

Gambar 8. Antarmuka Diagnosa CF

7) Antarmuka Riwayat

Pada antarmuka riwayat ini terdapat catatan berbagai hasil diagnosa yang pernah dilakukan user. Terdapat hasil persentasi diagnosa dengan metode yang digunakannya dan juga tombol untuk menghapus isi riwayat diagnosa.

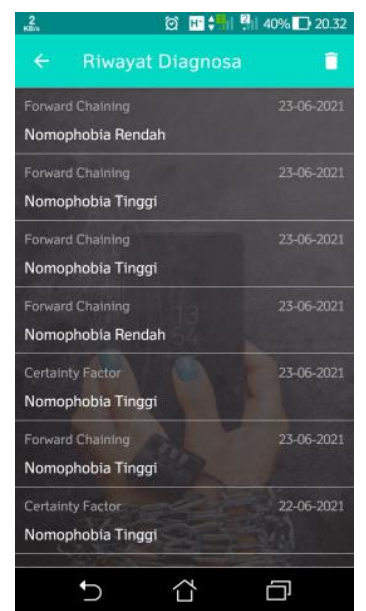

Gambar 9. Antarmuka Menu Riwayat

8) Antarmuka Tentang

Pada halaman ini terdapat keterangan singkat seputar kegunaan aplikasi diagnosa, informasi versi aplikasi dan pembuat aplikasi.

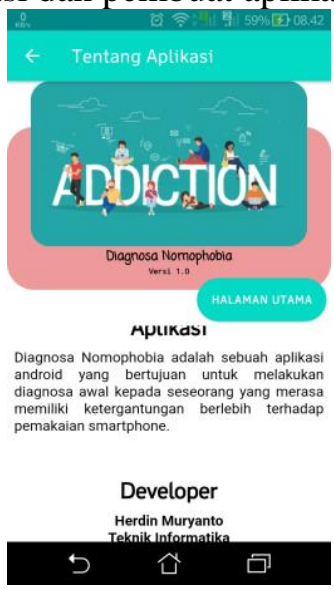

Gambar 10. Antarmuka Menu Tentang

\section{b. Pengujian Sistem}

Setelah melakukan pengujian Black Box pada 11 responden remaja menggunakan smartphone android dengan berbagai tipe untuk mengetahui fitur-fitur dalam aplikasi berjalan dengan baik, didapatkan tingkat keberhasilan 100\% yang dapat dilihat pada tabel 1.

Tabel 1. Hasil Test Black Box Aplikasi

\begin{tabular}{ccccc}
\hline Smartphone & Layar (inches) & RAM (GB) & Versi Andoid & Keberhasilan \\
\hline Zenfone 3 Max & 5.0 & $2 \mathrm{~GB}$ & Android 7.0 (Nougat) & $100 \%$ \\
Oppo Reno 5Lite & 6.4 & $8 \mathrm{~GB}$ & Android 11 & $100 \%$ \\
Galaxy J2 Prime & 5.0 & $1.5 \mathrm{~GB}$ & Android 6 (Marshmallow) & $100 \%$ \\
Vivo Y55s & 5.2 & $2 \mathrm{~GB}$ & Android 6 (Marshmallow) & $100 \%$ \\
Galaxy A11 & 6.4 & $2 \mathrm{~GB}$ & Android 10 & $100 \%$ \\
Meizu X8 & 6.2 & $4 \mathrm{~GB}$ & Android 8.0 (Oreo) & $100 \%$ \\
Meizu 16s & 6.2 & $6 \mathrm{~GB}$ & Android 9.0 (Pie) & $100 \%$ \\
Xiaomi Mi 9 & 6.3 & $6 \mathrm{~GB}$ & Android 9.0 (Pie) & $100 \%$ \\
Xiaomi Poco M3 & 6.5 & $4 \mathrm{~GB}$ & Android 10 & $100 \%$
\end{tabular}

Jurnal Ilmiah "Technologia" 


\begin{tabular}{cccccc} 
Lenovo K10 & 6.3 & $4 \mathrm{~GB}$ & Android 9.0 (Pie) & \multirow{2}{*}{$100 \%$} \\
Realme C2 & 6.1 & $3 \mathrm{~GB}$ & Android 9.0 (Pie) & $100 \%$ & \\
\hline Pengujian User Acceptance Test (UAT) & GJ8 & $\sqrt{ }$ & $\sqrt{ }$
\end{tabular}

dilakukan untuk mengetahui seberapa besar tingkat penerimaan pengguna dengan aplikasi diagnosa tersebut, yang dilakukan pada 11 remaja menggunakan 5 pertanyaan terkait keefektifan dan kegunaan aplikasi, mendapatkan hasil yang baik yaitu $84,21 \%$. Soal-soal kuisioner yang digunakan dalam tes UAT dapat dilihat lebih detail pada Tabel 2 yang setiap jawabanya diberi bobot: $A=4$, $\mathrm{B}=3, \mathrm{C}=2$ dan $\mathrm{D}=1$. Hasil pengujian UAT dapat dilihat pada Tabel 3.

Tabel 2. Pertanyaan User Acceptance test (UAT)

\begin{tabular}{lllll}
\hline No & \multicolumn{2}{c}{ Pertanyaan } & \multicolumn{3}{c}{ Jawaban } \\
& & A B C D \\
\hline 1 & $\begin{array}{l}\text { Tampilan menarik dari } \\
\text { penerapan sistem pakar } \\
\text { diagnosis nomophobia }\end{array}$ & & \\
2 & $\begin{array}{l}\text { Aplikasi yang mudah } \\
\text { digunakan }\end{array}$ & & \\
3 & $\begin{array}{l}\text { Fiturnya mudah dipahami } \\
4\end{array}$ & $\begin{array}{l}\text { Fitur-fitur dalam aplikasi } \\
\text { dapat diakses dengan baik }\end{array}$ \\
5 & $\begin{array}{l}\text { Aplikasi ini informatif } \\
\text { dalam } \\
\text { pengetahuan menambah } \\
\text { nomophobia }\end{array}$ \\
\end{tabular}

\begin{tabular}{lll}
\hline & \multicolumn{2}{c}{ Tabel 3. Hasil Test UAT } \\
\hline No & Pertanyaan & Tingkat Penerimaan \\
\hline 1 & Pertanyaan 1 & $84,25 \%$ \\
2 & Pertanyaan 2 & $82,75 \%$ \\
3 & Pertanyaan 3 & $87,5 \%$ \\
4 & Pertanyaan 4 & $85,8 \%$ \\
5 & Pertanyaan 5 & $80,75 \%$ \\
Rata - rata & $84,21 \%$ \\
\hline
\end{tabular}

Pada pengujian metode sistem pakar yang dibuat dengan menerapkan metode penalaran forward chaining dan metode pengukuran kepercayaan dengan certainty factor ini terdiri dari 3 level nomophobia dengan 8 gejala umum yang disusun ke tabel basis pengetahuan pada tabel 4 berikut. Tabel 4. Basis Pengetahuan

\begin{tabular}{cccc}
\hline Kode & L1 & L2 & L3 \\
\hline GJ1 & $\sqrt{ }$ & & \\
GJ2 & $\sqrt{ }$ & & \\
GJ3 & $\sqrt{ }$ & $\sqrt{ }$ & $\sqrt{ }$ \\
GJ4 & $\sqrt{ }$ & & \\
GJ5 & $\sqrt{ }$ & $\sqrt{ }$ & \\
GJ6 & $\sqrt{ }$ & $\sqrt{ }$ & $\sqrt{ }$ \\
GJ7 & $\sqrt{ }$ & $\sqrt{ }$ & $\sqrt{ }$
\end{tabular}

\section{Keterangan :}

- GJ1 = Gelisah saat jauh dari ponsel

- GJ2 = Gangguan panik

- GJ3 = Khawatir kehabisan baterai

- GJ4 = Gelisah saat tidak terhubung ke internet

- GJ5 = Terus-menerus memeriksa smartphone

- GJ6 = Tidak nyaman saat tidak dapat mengakses informasi melalui smartphone

- GJ7 = Terlalu sibuk dengan dunianya sendiri

- GJ8= Kehilangan identitas saat tidak bisa menggunakan media sosial.

Model basis penetahuan di Tabel 4 kemudian direpresentasikan menggunakan kaidah produksi (production rule) dalam bentuk IF-THEN yang menghasilkan 3 buah aturan seperti yang dapat dilihat pada Tabel 5 berikut.

Tabel 5. Basis Aturan

\begin{tabular}{ll} 
Kode & Aturan IF-THEN \\
\hline R1 & IF GJ1 AND GJ2 AND GJ3 AND \\
& GJ4 AND GJ5 AND GJ6 AND GJ7 \\
& AND GJ8 THEN L1 \\
R2 & IF GJ3 AND GJ5 AND GJ6 AND \\
& GJ7 AND GJ8 THEN L2 \\
R3 & IF GJ3 AND GJ6 AND GJ7 AND \\
& GJ8 THEN L3
\end{tabular}

Untuk memberikan persentase keyakinan pada metode Certainty Factor terdapat 2 jenis nilai $\mathrm{CF}$ yang digunakan, yaitu $\mathrm{CF}_{\text {user }}$ dan $\mathrm{CF}_{\text {pakar }}$. Untuk $\mathrm{CF}_{\text {pakar }}$ setiap kondisi diberikan nilai 0,8 sedangkan pada $\mathrm{CF}_{\text {user }}$ dapat dilihat pada Tabel 6. Proses penghitungan nilai $\mathrm{CF}$ melalui dua tahapan, yaitu secara paralel dan kombinasi.

$$
\begin{aligned}
& C F(H \mid E)_{\text {paralel }}=C F(E)_{\text {user }} \times C F(E)_{\text {pakar }} \\
& C F(H \mid C F 1, C F 2)_{\text {kombinasi }}=C F 1+C F 2(1-C F 1)
\end{aligned}
$$

Tabel 6. Nilai CFuser

\begin{tabular}{|l|l|}
\hline Kondisi & Nilai CF \\
\hline Tidak & 0,1 \\
\hline Tidak Yakin & 0,3 \\
\hline Sedikit Yakin & 0,5 \\
\hline Yakin & 0,7 \\
\hline Sangat Yakin & 0,8 \\
\hline \multicolumn{2}{|c|}{ Pengujian metode sistem dilakukan dar }
\end{tabular}

Pengujian metode sistem dilakukan dari 17 data uji coba pada setiap level nomophobia sesuai tingkat fobia Nomophobia dengan hasil seperti terlihat pada Tabel 7 dibawah ini. 
Tabel 7. Hasil Test Metode Sistem

\begin{tabular}{|c|c|c|c|c|}
\hline Data Uji & Gejala & Manual Pakar & Sistem & Validasi \\
\hline D1 & Gj3, Gj5, Gj6, Gj7, Gj8 & sedang & sedang & sesuai \\
\hline D2 & Gj1, Gj2, Gj3, Gj4, Gj5, Gj6, Gj7, Gj8 & tinggi & tinggi & sesuai \\
\hline D3 & Gj3, Gj6, Gj7, Gj8 & ringan & ringan & sesuai \\
\hline D4 & $\mathrm{Gj} 3, \mathrm{Gj} 6, \mathrm{Gj} 7, \mathrm{Gj} 8$ & ringan & ringan & sesuai \\
\hline D5 & Gj3, Gj5, Gj6, Gj7, Gj8 & sedang & sedang & sesuai \\
\hline D6 & $\mathrm{Gj} 3, \mathrm{Gj} 6, \mathrm{Gj} 7, \mathrm{Gj} 8$ & ringan & ringan & sesuai \\
\hline D7 & Gj1, Gj2, Gj3, Gj4, Gj5, Gj6, Gj7, Gj8 & tinggi & tinggi & sesuai \\
\hline D8 & Gj3, Gj5, Gj6, Gj7, Gj8 & sedang & sedang & sesuai \\
\hline D9 & Gj3, Gj5, Gj6, Gj7, Gj8 & sedang & sedang & sesuai \\
\hline D10 & Gj3, Gj5, Gj6, Gj7, Gj8 & sedang & sedang & sesuai \\
\hline D11 & $\mathrm{Gj} 3, \mathrm{Gj} 5, \mathrm{Gj} 6, \mathrm{Gj} 7, \mathrm{Gj} 8$ & sedang & sedang & sesuai \\
\hline D12 & Gj3, Gj5, Gj6, Gj7, Gj8 & sedang & sedang & sesuai \\
\hline D13 & Gj1, Gj2, Gj3, Gj4, Gj5, Gj6, Gj7, Gj8 & tinggi & tinggi & sesuai \\
\hline D14 & Gj3, Gj5, Gj6, Gj7, Gj8 & sedang & sedang & sesuai \\
\hline D15 & Gj3, Gj6, Gj7, Gj8 & ringan & ringan & sesuai \\
\hline D16 & Gj3, Gj5, Gj6, Gj7, Gj8 & sedang & sedang & sesuai \\
\hline D17 & Gj1, Gj2, Gj3, Gj4, Gj5, Gj6, Gj7, Gj8 & tinggi & tinggi & sesuai \\
\hline $\mathrm{Ber}$ & pel 7 terdapat $17 \mathrm{~d}$ & \multicolumn{2}{|c|}{ Rata-rata } & 80,72 \\
\hline
\end{tabular}

untuk nomophobia rendah, 9 data untuk nomophobia sedang dan 4 data untuk nomophobia tinggi. Pengujian menggunakan aplikasi diagnosa nomophobia dengan metode referensi forward chaining didapatkan hasil diagnosa psikolog dan diagnosa sistem diperoleh tingkat akurasi sebesar $100 \%$.

Sedangkan persentase keyakinan pada hasil penalaran metode forward chaining yang dicari menggunakan metode certainty factor mendapatkan nilai rata-rata sebesar $74 \%$ dari 11 responden remaja SMK.

\begin{tabular}{cll}
\hline Responden & \multicolumn{1}{c}{ Nomophobia } & CF \\
\hline R1 & Nomophobia tinggi & 88 \\
R2 & - & 43 \\
R3 & Nomophobia Sedang & 97 \\
R4 & Nomophobia Sedang & 70 \\
R5 & Nomophobia ringan & 94 \\
R6 & Nomophobia Sedang & 87 \\
R7 & Nomophobia ringan & 89 \\
R8 & - & 56 \\
R9 & nomophobia tinggi & 82 \\
R10 & Nomophobia Sedang & 96 \\
R11 & Nomophobia ringan & 86
\end{tabular}

\section{KESIMPULAN DAN SARAN \\ a. Kesimpulan}

Berdasarkan pada hasil pembahasan yang telah dilakukan diatas dapat diambil kesimpulan bahwa:

1. Aplikasi sistem pakar diagnosa nomophobia ini ini memberikan kemudahan dalam penggunaannya, dengan cara membuka aplikasi, kemudian melakukan diagnosa pada menu quiz, lalu user tinggal menjawab pertanyaanpertanyaan yang ada, maka akan muncul hasil dari diagnosa dari nomophobia berdasarkan level kecanduan ponselnya.

2. Pada penelitian ini dilakukan 3 pengujian yaitu pengujian blackbox, UAT dan akurasi sistem. Dari hasil pengujian blackbox diketahui bahwa sistem dapat bekerja dengan baik dengan tingkat penerimaan aplikasi sebesar 84,21\%. Selanjutnya dilakukan uji akurasi sistem dari hasil 17 kali uji coba, didapatkan akurasi $100 \%$ antara diagnosa manual dari pakar dengan sistem dan diagnosa tingkat keyakinan pada 11 remaja menghasilkan $74,54 \%$. 
3. Aplikasi ini dapat pula digunakan dimana saja dan kapan saja karena diaplikasikan dalam Smartphone Android.

\section{b. Saran}

Dari hasil penelitian yang telah dilakukan tersebut, maka terdapat saran yang dapat diberikan peneliti untuk penelitian selanjutnya, yaitu sebagai berikut :

1. Saran untuk pengembangan penelitian selanjutnya dapat dikembangkan dengan menambahkan metode lain untuk melakukan diagnosa dini nomophobia pada remaja agar mendapatkan hasil tes yang lebih akurat.

2. Penggunaan media internet atau sistem berbasis web yang terintergrasi dengan aplikasi untuk mempermudah pengguna memperoleh informasi lebih banyak seputar nomophobia sehingga aplikasi ini dapat lebih memberi pengetahuan seputar nomophobia.

\section{REFERENSI}

Ezemenaka, E. (2013). The usage and impact of Internet enabled phones on academic concentration among students of tertiary institutions: A study at the University of Ibadan, Nigeria. Int J Educ Dev Using Inf, Vol. 9, Issue 3, 162-173.

Ibrohim, M., \& Purwanty, N. (2017). Rancang Bangun Aplikasi Identifikasi Gaya Belajar Siswa Dengan Metode Forward Chaining. Pro TekInfo, Vol. 4, ISSN : 2406-7741.

King, A., \& dkk. (2014). Nomophobia: Impact of Cell Phone Use Interfering with Symptoms and Emotions of Individuals with Panic Disorder Compared with a Control Group. Clinical Practice \& Epidemiology in Mental Health, Vol.10, 28-35.

Nareza, M. (2020, September 8). alodokter.com. Retrieved from Hati-Hati Dampak Negatif HP bagi Kesehatan: https://www.alodokter.com/hati-hatimenggunakan-ponsel-berlebihan-bisamemicu-penyakit-ini

Putri, A., \& Rifki, K. (2020). Aplikasi Sistem Pakar Diagnosa Tingkat Depresi Pada Remaja Metode Forward Chaining Berbasis Android. Jurnal Ilmiah Informatika Komputer, Vol.25, 15-22.

Rahayuningrum, D. C., \& Sary, A. N. (2019). Studi Tingkat Kecemasan Remaja Terhadap No-Mobile Phone (Nomophobia) Di Sma Negeri Kota

Jurnal Ilmiah "Technologia"
Padang. Jurnal Keperawatan BSI, Vol.7, No.1, 2338-7246, Vol. 2, No. 1, ISSN : : $2503-250 X, 34-37$.

Sari, I. p., Ifdil, \& Yendi, F. M. (2020). Konsep Nomophobia pada Remaja Generasi Z. JRTI (Jurnal Riset Tindakan Indonesia), Vol. 5, No. 1, ISSN : 2503-1619, 21-26.

Supiandi, A., \& Chandradimuka, D. B. (2018). Sistem Pakar Diagnosa Depresi Mahasiswa Akhir Dengan Metode Certainty Factor Berbasis Mobile. JURNAL INFORMATIKA, Vol.5 No. 1, ISSN : 2355-6579, 102-111. 